
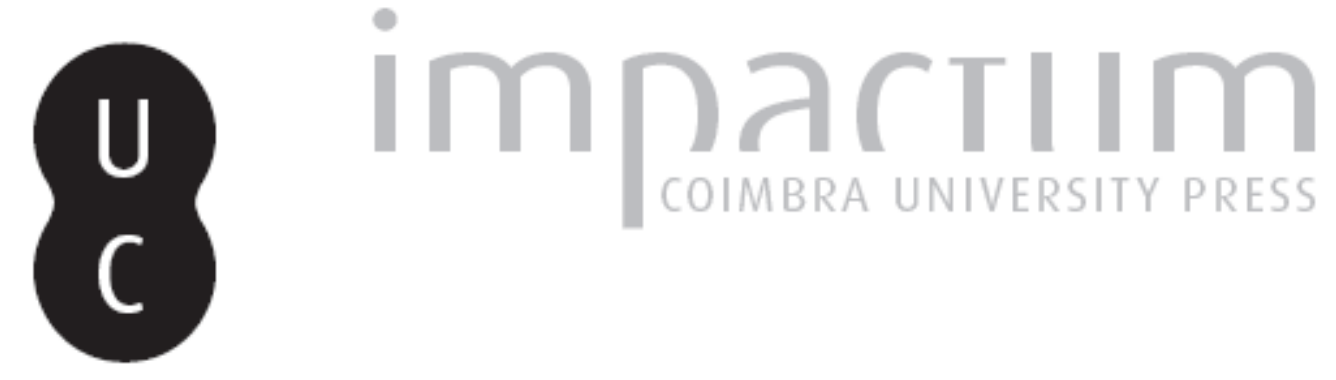

\title{
Os agremiados, os contribuintes e o tecido comercial: os Grémios do Comércio de Braga e Guimarães: 1944-1955
}

Autor(es): $\quad$ Torres, Jorge Mano

Publicado por: Imprensa da Universidade de Coimbra

URL persistente:

URI:http://hdl.handle.net/10316.2/44855

DOI:

DOI:https://doi.org/10.14195/1647-8622_18_4

Accessed : $\quad$ 26-Apr-2023 10:42:42

A navegação consulta e descarregamento dos títulos inseridos nas Bibliotecas Digitais UC Digitalis, UC Pombalina e UC Impactum, pressupõem a aceitação plena e sem reservas dos Termos e Condições de Uso destas Bibliotecas Digitais, disponíveis em https://digitalis.uc.pt/pt-pt/termos.

Conforme exposto nos referidos Termos e Condições de Uso, o descarregamento de títulos de acesso restrito requer uma licença válida de autorização devendo o utilizador aceder ao(s) documento(s) a partir de um endereço de IP da instituição detentora da supramencionada licença.

Ao utilizador é apenas permitido o descarregamento para uso pessoal, pelo que o emprego do(s) título(s) descarregado(s) para outro fim, designadamente comercial, carece de autorização do respetivo autor ou editor da obra.

Na medida em que todas as obras da UC Digitalis se encontram protegidas pelo Código do Direito de Autor e Direitos Conexos e demais legislação aplicável, toda a cópia, parcial ou total, deste documento, nos casos em que é legalmente admitida, deverá conter ou fazer-se acompanhar por este aviso.

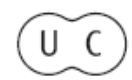




\section{ESTUDOSDOSÉCULO}

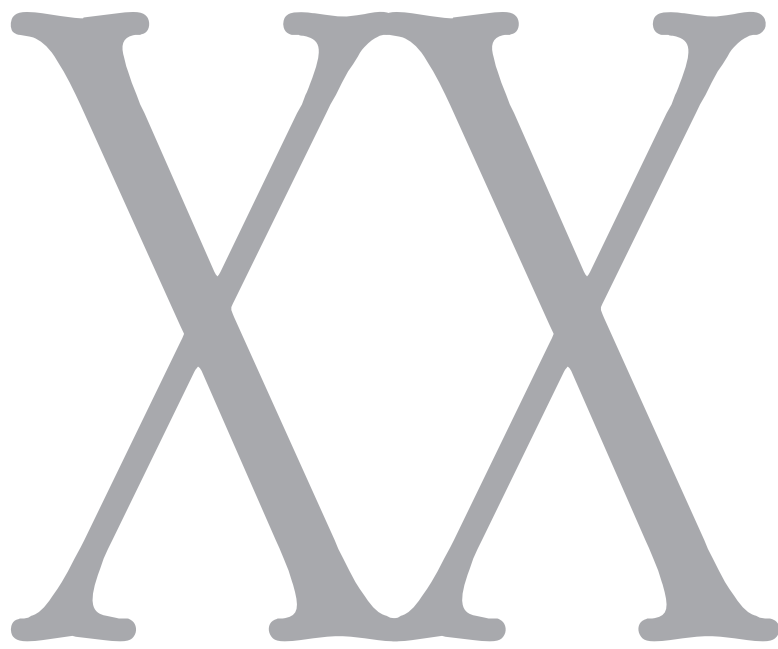

número $18 \bullet 2018$

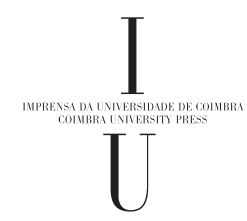




\section{Os agremiados, os contribuintes e o tecido comercial \\ Os Grémios do Comércio de Braga e Guimaráes, 1944-1955}

\section{Guild members, taxpayers and the business fabric. \\ Trade Guilds in Braga and Guimarães, 1944-1955

$$
\text { Jorge Mano Torres }
$$

Jorge Mano Torres, Investigador do Instituto de História Contemporânea da Faculdade de Ciências Sociais e Humanas da Universidade Nova de Lisboa. Email: jorgemanotorres@hotmail.com. 
OS AGREMIADOS, OS

CONTRIBUINTES E O TECIDO

COMERCIAL. OS GRÉMIOS DO

COMÉRCIO DE BRAGA

E GUIMARĀES, 1944-1955

Os grémios, organismos corporativos patronais, surgiram enquadrados no corporativismo e na sua organização, instituído pelo Estado Novo, como uma resposta política e económico-social a uma situaçáo de crise e com perigos à espreita (crise de 1929 e II Guerra Mundial), numa economia com vulnerabilidades estruturais. O regime instaurado defendia uma lógica de organização económica e social, privilegiando o interesse geral, através de uma harmonia entre os vários intervenientes do mercado, que o próprio Estado controlava. É neste contexto político-ideológico que surgem as corporaçôes e os grémios, que iriam controlar as decisôes económicas nacionais, constituindo os grémios (a par dos sindicatos nacionais, casas do povo e casas dos pescadores) a base da organizaçâo corporativa, tendo como principais funçóes a representação profissional e a defesa de categoria económica.

Os grémios do comércio de Braga e Guimarães foram oficialmente instituídos em Junho e Abril de 1940, respetivamente, resultando da transformação das anteriores associações comerciais, que estavam ameaçadas de dissolução caso optassem por não aderir à política corporativa instaurada pelo Estado Novo, vindo a desaparecer após a Revolução de 25 de Abril de 1974, e do consequente desmantelamento da estrutura corporativa. Com recurso aos arquivos de ambos os organismos, na posse das associaçôes comerciais de Braga e Guimarães, tem-se como objectivo analisar o tecido comercial criado pelos organismos bracarense e vimaranense, nas suas dimensôes, diversidade e peso económico.

Palavras-chave: Estado Novo, Corporativismo, Organismos Corporativos, Autoritarismo, Grémios do Comércio.
GUILD MEMBERS, TAXPAYERS AND THE BUSINESS FABRIC. TRADE GUILDS IN BRAGA AND GUIMARÁES, 1944-1955

The guilds, corporative employers' organizations, emerged within the framework of corporatism and its organization, instituted by the Estado Novo, as a political and economic-social response to a crisis situation and with dangers lurking (crisis of 1929 and World War II), in an economy with structural vulnerabilities. The regime established was based on a logic of economic and social organization, giving priority to the general interest, through a harmony between the various market players, which the State itself controlled. It is in this political-ideological context that the corporations and the federations, that would control the national economic decisions, emerge, constituting the guilds (along with the national trade unions, houses of the people and houses of fishermen) the basis of the corporate organization, having as main functions the professional representation and the defence of economic category.

Braga and Guimarães commercial guilds were officially established in June and April 1940, respectively, resulting from the transformation of previous trade associations, which were threatened with dissolution if they chose not to adhere to the corporate policy established by Estado Novo, coming to disappear after the Revolution of April 25, 1974 , and the consequent dismantling of the corporate structure. With the use of the archives of both organizations, in possession of the trade associations of Braga and Guimaráes, respectively, the objective is to analyse the commercial fabric created by both organisms, in their dimensions, diversity and economic weight.

Keywords: Estado Novo, Corporatism, Corporate Organisms, Authoritarianism, Commercial Guilds.
LES ASSOCIÉS, LES CONTRIBUABLES ET LE TISSU COMMERCIAL. LES CERCLES DU COMMERCE DE BRAGA ET GUIMARÁES, 1944-1955

Les cercles, organismes corporatifs patronaux, sont nés encadrés dans le corporatisme et son organisation, institué par l'État Nouveau, en tant que réponse politique et économico-sociale à une situation de crise et avec des dangers qui guettent (crise de 1929 et Deuxième Guerre Mondiale), dans une économie ayant des vulnérabilités structurelles. Le régime instauré défendait une logique d'organisation économique et sociale, privilégiant l'intérêt général, grâce à une harmonie entre les différents intervenants du marché que l'État lui-même contrôlait. C'est dans ce contexte politico-idéologique que sont nés les corporations et les cercles qui allaient contrôler les décisions économiques nationales, les cercles (avec les syndicats nationaux, les maisons du peuple et les maisons des pêcheurs) constituant la base de l'organisation corporative, leurs principales fonctions étant la représentation professionnelle et la défense d'une catégorie économique. Les cercles du commerce de Braga et de Guimarães ont officiellement été institués en juin et avril 1940, respectivement, et étaient le résultat de la transformation des associations commerciales précédentes qui étaient menacées de dissolution si elles ne choisissaient pas d'adhérer à la politique corporative instaurée par l'État Nouveau. Ils ont disparu après la Révolution du 25 avril 1974 et le démantèlement conséquent de la structure corporative. À l'aide des archives des deux organismes, détenues par les associations commerciales de Braga et de Guimarães, l'objectif est d'analyser le tissu commercial créé par les organismes de Braga et de Guimarães, dans ses dimensions, diversité et poids économique.

Mots clés: État Nouveau, Corporatisme, Organismes corporatifs, Autoritarisme, Cercles du commerce. 


\section{Das associações comerciais de Braga e Guimarães aos Grémios do Comércio} dos Concelhos de Braga e Guimarães

A Associação Comercial de Braga (ACB) nasceu em 1863, por iniciativa de um grupo de comerciantes. Pouco se sabe acerca dos primeiros anos da ACB, já que um violento incêndio, em 1905, destruiu praticamente toda a documentaçáo original. No momento da fundação da ACB, e de acordo com Eduardo Pires de Oliveira, Braga estava em pleno desenvolvimento e que "com a renovaçáo que se sentira na década anterior tinham sido inauguradas, ou dado início, a um conjunto de obras relevantes [...] Teatro S. Geraldo, o Jardim Público, a conclusão do edifício da Câmara Municipal, a iluminaçáo pública com candeeiros a gaz, a Biblioteca Pública, o cemitério, um novo depósito de águas e, sobretudo, um conjunto de estradas que passaram a permitir uma fácil ligação com a cidade do Porto, com o Alto-Minho e com a vizinha Guimarães"'.

Guimarães, "núcleo mercantil e manufactureiro de uma das mais activas regiôes minhotas (...) que durante longos séculos manteve uma organização corporativa exemplar" ${ }^{2}$, desde cedo se destacou a nível industrial, com os seus industriais e artesãos a marcarem presença em grandes feiras industriais um pouco por todo o mundo, tendo estas actividades ${ }^{3}$ um grande destaque no concelho, ao ponto de se ter ali realizado a primeira exposição industrial concelhia do país, em 1884. Para uma regulação eficaz das actividades ligadas ao comércio dos produtos industriais, foram criadas "estruturas associativas capazes de defender os interesses da classe" ", sendo a Associaçáo Comercial de Guimarães (ACG) a terceira no norte do país (atrás apenas das associaçôes de Porto, 1834 e Braga, 1863), o que sugere, além de uma intensa actividade industrial e comercial, uma forte tradição associativa no concelho vimaranense.

É em 1865 que a ACG dá os seus primeiros passos. As associaçóes comerciais - associaçóes de classe patronais - tinham objectivos de representação, promoção e defesa dos interesses colectivos, neste caso específico, dos interesses do comércio. As primeiras associaçōes patronais estavam precisamente ligadas à actividade comercial

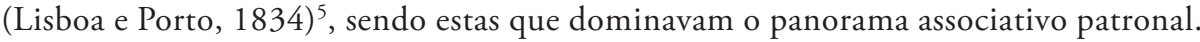

Numa reunião organizada em Março de 1865 compareceram 97 comerciantes, motivados pelo desejo de criar uma associação comercial que defendesse os seus interesses. A criação oficial da ACG só viria a acontecer a três de Outubro, por alvará régio, subscrito pelo rei D. Luís e pelo Ministro e Secretário de Estado das Obras Públicas, Comércio e Indústria.

No início da década de 1920 presidia à Direcção Eduardo D’Almeida, com ideias concretas para a reorganização associativa, com destaque para uma nova reforma dos

\footnotetext{
${ }^{1}$ OliVEIRA, Eduardo Pires de - História da Associação Comercial de Braga. Braga: Associação Comercial de Braga, 2000. p. 39

${ }^{2}$ BASTOS, Carlos - Livro de Ouro do Comércio e Indústria de Portugal. Porto: Edição de autor, 1957. p. 49.

${ }^{3}$ Os principais produtos eram os linhos, as cutelarias, os curtumes, a ourivesaria, o vinho, o papel, as sedas, fruta seca e doce, sabōes, colas, pentes, licores e a arboricultura.

${ }^{4}$ CACHADA, Armindo - Associação Comercial e Industrial de Guimarães, Subsídios para a sua história. Boletim Informativo Edição Especial, 125 anos. (1990) p. 18.

${ }^{5}$ Entre 1834 e 1891 surgem 14 associaçóes comerciais, entre as quais se conta a de Guimarães (1865).
} 
Estatutos, tendo por objectivo a inclusão da classe industrial na associação, dando origem à Associação Comercial e Industrial de Guimarães (ACIG).

Entre 1936 e 1939, parece não existir qualquer actividade da direcção, indicador de um período de crise associativa. A 25 de Maio de 1939 é convocada a Direcção, para uma reuniáo extraordinária, na sequência de uma reuniáo dos credores que tinham subscrito a compra do edifício sede. Aí é dado conhecimento aos sócios de uma reunião a realizar a 26 de Junho, com vista à transformação da ACIG no Grémio do Comércio do Concelho de Guimarães (GCCG). A 30 desse mês decorre a última reuniâo da ACIG, que marca também o final da sua primeira fase de actividade, depois de 74 anos de vida, "integrando-se na evolução social do País que preconizava quadros económicos modelados sob concepçóes de novo carácter, a colectividade ia transformar-se em grémio patronal, aderindo assim à estrutura do Estado Corporativo saído da Revolução de 28 de Maio".

A 31 de Julho de 1939 teve então lugar a primeira reuniáo da Comissão Organizadora do GCCG (composta por membros das extintas ACIG e da Associação Comercial de Revendedores de Vinhos e Víveres). A principal preocupação dos organizadores era a elaboraçáo de um projecto de Estatutos enquadrado na organização corporativa instaurada pelo Estado Novo. A 20 de Abril de 1940 os Estatutos foram aprovados por alvará do Subsecretário de Estado das Corporaçôes e Previdência Social, criando-se oficialmente o GCCG. Segundo Carlos Bastos, este organismo continuou a ser "o porta-voz dos interesses regionais e o propulsionador das energias mercantis e industriais da sua terra" ${ }^{7}$, tratando de questôes relativas ao progresso da cidade e dinamizando as suas empresas mais importantes, sempre em colaboração com entidades superiores, subordinado às instituiçóes vigentes.

Também em Braga a transformação da ACB em Grémio do Comércio do Concelho de Braga (GCCB) decorreu de forma tranquila, em Maio de 1939, com a Assembleia-geral a aprovar a proposta do Presidente da Direcção, Casimiro Cunha e Silva, para a adopção dos princípios do Estado Corporativo.

\section{O Estado Novo e o Corporativismo}

Em 1926 um golpe militar pôs fim à Primeira República e instaurou uma Ditadura Militar que culminou com a implementaçáo do Estado Novo em 1933. Foi Salazar quem conseguiu criar as condiçôes de estabilidade política e ideológica para que as diferentes direitas se unissem no compromisso de estabelecer um regime autoritário estável e duradouro.

A Constituição de 1933, que marca o início do regime, proclamava uma república unitária e corporativa, entre princípios liberais e corporativos. O corporativismo, enquanto instrumento de controlo e disciplina social do movimento operário e sindical e "principal quadro orgânico de regulação e equilíbrio entre os diversos sectores da

\footnotetext{
${ }^{6}$ BASTOS, Carlos - Livro de Ouro do Comércio e Indústria de Portugal, p. 52.

${ }^{7}$ Ibidem.
} 
classe dominante" ${ }^{8}$, representa, de acordo com Fernando Rosas na sua obra Salazar e o Poder..., um dos principais factores de longevidade política do Estado Novo.

O estudo do corporativismo tem vindo a ser, dominantemente, alvo de trabalhos centrados no seu carácter ideológico e doutrinário, seguindo as fontes legadas pelo regime ${ }^{9}$. O corporativismo, afirma Lucena, constrói-se pelo telhado, apoderando-se do Estado, fabricando "um corporativismo de coacção, lacunar, distorcido, ostensivamente autoritário (...) fatalmente subordinado: praticamente, senão também doutrinariamente, será do Estado" ${ }^{10}$. E na prática foi-o: um corporativismo estatal, parcial e subordinado ${ }^{11}$. O estudo do corporativismo deve ter em conta, assim, o discurso ideológico e realização prática $^{12}$. As incoerências entre teoria e prática estão já identificadas, faltando estudos que permitam compreender o funcionamento da dinâmica corporativa e o seu impacto na sociedade, designadamente como esta reagiu à organização corporativa, de baixo para cima $^{13}$; ainda que mais recentemente tenham surgido novos contributos ao nível do que foi a construção do direito público do regime e do lugar que aí ocupou o referencial corporativo ${ }^{14}$.

O corporativismo português surgiu enquadrado numa vaga corporativa onde se destacaram os casos da Itália de Mussolini e da Espanha de Franco. O corporativismo italiano - uma versão possível de actuaçáo ${ }^{15}$ - teria servido de inspiração para as ditaduras corporativas ibéricas e latinas. Vários autores defendem que a Carta del Lavoro é a base do Estatuto do Trabalho Nacional e do Fuero del Trabajo, apesar de o corporativismo português se distinguir destas formas de corporativismo pelo próprio Estatuto do Trabalho Nacional e também pela organização corporativa do trabalho. No caso português o regime criou organismos distintos dos casos italiano ou espanhol - além dos sindicatos, foram criados grémios, casas do povo e dos pescadores - regulados/ fiscalizados pelo Instituto Nacional do Trabalho e Previdência (INTP), que reunia todas as competências públicas de administração e inspecção do trabalho, exercendo o controlo do Estado sobre as relaçóes laborais ${ }^{16}$.

O propósito do corporativismo era constituir um meio de atingir "objectivos de equilíbrio e harmonia social" ${ }^{17}$, ambicionados pelos seus mentores, com o Estado

\footnotetext{
${ }^{8}$ ROSAS, Fernando - Salazar e o poder: a arte de saber durar. Lisboa: Tinta-da-China, 2012. p. 281.

${ }^{9}$ Cfr. ROSAS, Fernando; GARRIDO, Álvaro - Corporativismo, Fascismos, Estado Novo. Coimbra: Almedina, 2012.

${ }^{10}$ LUCENA, Manuel de - A evolução do sistema corporativo português. Lisboa: Perspectivas \& Realidades, 1976. p. 105.

${ }^{11}$ Cfr. ESTÊVÃO FERREIRA, Nuno - "O corporativismo e as instituiçôes do salazarismo: a Câmara Corporativa (1935-1945)”. In O Corporativismo em Português. Lisboa: Imprensa da Ciências Sociais, 2008.

${ }^{12}$ Cfr. ROSAS, Fernando - Salazar...

${ }^{13}$ Cfr. GARRIDO, Álvaro - "Estado corporativo, economia institucionalizada”. In Estado, Regimes e Revoluçóes: Estudos em homenagem a Manuel de Lucena. Lisboa: Imprensa das Ciências Sociais, 2012.

${ }^{14}$ Cfr. SANTOS, Paula Borges - "O modelo político do Estado autoritário Português: A ideia corporativa na constitucionalização do regime (1931-1933)”. Espacio Tiempo y Forma. Serie V, Historia Contemporánea. Vol. 0, n. ${ }^{\circ} 27$ (2015) p. 59-84.

${ }^{15}$ Cfr. GAGLIARDI, Alessio - Il corporativismo fascista. Bari: Gius, Laterza \& Fligi, 2010.

${ }^{16}$ Cfr. RODRIGUES, Cristina - Portugal e a Organização Internacional do Trabalho (1933-1974). Porto: Afrontamento, 2013.

${ }^{17}$ CARDOSO, José Luís - “Corporativismo, Instituiçōes Políticas e Desempenho Económico”. Em Corporativismo, Fascismos, Estado Novo. Coimbra: Almedina, 2012. p. 102.
} 
a desempenhar um papel fulcral, tendo-se como indispensável na sua função de regulação e controlo da vida económica e social do país, visto como "um conjunto coeso e organizado" 18 .

Era assim defendida uma lógica de organização económica e social que privilegiava o interesse geral, através da harmonia entre os vários intervenientes do mercado, controlado pelo próprio Estado. As corporaçôes e os grémios arrogavam as decisôes económicas nacionais (fixação de preços, entrada de novas empresas no mercado, regulação das condições de trabalho, etc.) possuindo "capacidade e garantias de representatividade nacional e sectorial das actividades económicas" ${ }^{19}$. O Estado (através do corporativismo) sobrepunha-se ao indivíduo - que se submetia aos desígnios da nação, deixando de existir livre concorrência em prol dos ideais de cooperação e solidariedade - subjugando a luta de classes. $\mathrm{O}$ modelo corporativo impóe um sistema de valores que interfere no modo de organização da vida económica e, mais do que sistema, é organização. Tendo sido à partida definido como instrumento de prevenção da conflitualidade social, jamais essa posição vem a ser corrigida. Assim, trata-se de uma forma de disciplinar o capital e o trabalho, subjugando os interesses económicos aos interesses nacionais, tornando-o um poderoso instrumento do Estado sobre a sociedade.

O nacionalismo corporativo foi um dos grandes princípios positivos do Estado Novo. Os interesses do indivíduo ficavam sujeitos aos interesses e objectivos da nação (nacionalismo), sujeição conseguida através da construção do Estado social corporativo, legitimado nos "organismos componentes da naçáo" ${ }^{20}$ - as famílias, freguesias, municípios e corporações - com intervenção directa na constituição do Estado.

É no sentido desta política que é instituída a organização corporativa. Predominantemente económica, tendo motivações políticas, isto é, "a reorganização da economia participou do processo de reconstrução do Estado" ${ }^{21}$, esta organização corporativa da economia, instituída de baixo para cima, como afirma Manuel de Lucena $^{22}$, revelou-se um dos mais fortes componentes do Estado Novo. Estruturada em três planos: organismos primários (sindicatos, grémios, casas do povo e casas dos pescadores); organismos intermédios (federaçôes e uniōes); e corporações. "Na base da pirâmide encontravam-se os (...) grémios (...) sindicatos nacionais, casas do povo e casas dos pescadores. Num segundo nível, estes organismos podiam constituir, de acordo com o respectivo modelo institucional, federaçôes ou uniôes" ${ }^{23}$.

Os grémios ${ }^{24}$, elementos primários da organização corporativa patronal, surgiam assim como órgãos de intervenção económica com vastos poderes de regulação nos

\footnotetext{
${ }^{18}$ Ibidem.

${ }^{19}$ Ibid., p. 103.

${ }^{20}$ ROSAS, Fernando - "Portugal e o Estado Novo". In Nova História de Portugal. Lisboa: Presença, 1987, p. 97.

${ }^{21}$ GARRIDO, Álvaro - "Contexto, fundamentos e lógicas de construção da economia nacional corporativa”. In Corporativismo, Fascismos, Estado Novo. Coimbra: Almedina, 2012. p. 152.

${ }^{22}$ Cfr. LUCENA, Manuel de - A evolução do sistema corporativo português.

${ }^{23}$ FREIRE, Dulce; ESTÊVÃO FERREIRA, Nuno; RODRIGUES, Dulce - Corporativismo e Estado Novo. Contributo para um roteiro de arquivos das instituiçōes corporativas (1933-1974). Lisboa: ICS Working Papers, 2014. p. 13 .

${ }^{24}$ Existem três tipos de grémios com regimes jurídicos próprios, mas disposiçôes comuns, os grémios obrigatórios (presentes em todos os sectores da economia), os facultativos do comércio e indústria (no qual se encaixa o GCCG) e os da lavoura.
} 
respectivos sectores, com o objectivo de regular as relaçóes entre capital e trabalho (do lado dos patrốes), tendo a sua origem da necessidade de cartelização patronal como resposta a situaçóes sectoriais de crise. Controlados rigorosamente pelo Estado, através do INTP ou dos organismos sectoriais de coordenação económica, os primeiros grémios do comércio, indústria ou de produtos agrícolas (que são também os principais) tinham inscrição obrigatória, sendo criados pelo Governo; a sua área de actuação e funções eram determinados pelo Estado, que designava os respectivos corpos gerentes. Ainda assim, também os grémios facultativos funcionavam na mesma linha dos grémios obrigatórios (transformando-se muitas vezes em organismos obrigatórios). A gestão destes organismos dependia de aprovação governamental prévia, com o Governo a vigiar e orientar a sua actividade através do INTP e dos organismos de coordenação económica.

O sistema gremial fica marcado por uma grande complexidade, consequência de diversos factores: as principais funçóes que lhes eram atribuídas - representação profissional e defesa da categoria económica - implicavam uma grande variedade de tarefas relacionadas com a contratação colectiva, a previdência e a acção social, a realização de estudos e o fomento das actividades e também da disciplinação do próprio sistema económico que os grémios representavam, já que o seu raio de acção variava de acordo com as exigências de cada ramo de actividade, existindo grémios distritais, concelhios (mais limitados), pluriconcelhios ${ }^{25}$ e até nacionais, dando-se também a separação entre grossistas e retalhistas (existindo ainda organismos mistos); e a coexistência de grémios facultativos e obrigatórios, os primeiros criados pelos interessados sem inscrição obrigatória, os segundos criados pelos ministérios económicos, com inscrição obrigatória para o exercício da actividade (no entanto, em muitos grémios facultativos o Estado substitui a iniciativa privada, instituindo a inscrição obrigatória).

Com a nova ideologia política e económica defendida pelo Estado Novo a existência das associaçóes comerciais era posta em xeque por uma legislação de carácter obrigacionista, que impunha a mão do Estado na administração das várias associaçóes comerciais existentes, assumindo o Estado um papel cada vez mais presente e, podemos mesmo dizer, dominador.

As mudanças foram muitas, e a orientação dos novos organismos passavam por alteraçóes de fundo relativamente ao momento anterior. No caso da ACIG, por exemplo, se até 1939 a sua preocupação havia sido sempre a defesa dos interesses do comércio/indústria, dos seus comerciantes/industriais e a promoção do desenvolvimento do concelho, com o surgimento do Grémio, o comércio e os comerciantes ficam em segundo plano, ao passo que os interesses industriais desaparecem por completo. O organismo passa a constituir um braço do Estado, com o principal objectivo de disciplinar as actividades comerciais que representa, estando constantemente subordinado (e subordinando os seus afiliados) aos interesses do Estado e da política nacional, através da organização corporativa, da qual os grémios constituem elemento primário.

\footnotetext{
${ }^{25}$ No distrito de Braga, dos seis grémios comerciais existentes, apenas os Grémios de Braga e Fafe diferem desta configuração, tendo carácter pluriconcelhio (abarcam vários concelhos no seu raio de acção). Esteve prevista a adopçáo deste estatuto para o GCCG, que passaria a abranger os concelhos de Póvoa de Lanhoso e de Vieira do Minho, mas a vontade dos comerciantes daqueles concelhos ditou a sua inclusão no GCCB.
} 
Em 1939, dá-se então uma importante mudança no associativismo comercial, com a transformação das associações comerciais em grémios do comércio retalhista misto, na sequência do Decreto-Lei n. ${ }^{\circ} 29232$ de 8 de Dezembro de 1938 que definiu os moldes da integração das associações patronais na organização corporativa. Este Decreto-Lei tinha a finalidade de regular a integração na organização corporativa das associaçóes patronais constituídas ao abrigo do decreto de 9 de Maio de 1891, surgindo na sequência da impossibilidade de adaptação das associaçôes com uma estrutura heterogénea (associaçóes comerciais e industriais, como era o caso da ACIG).

Nesse sentido, as associaçóes deveriam requerer autorização do Governo para se integrarem na organização corporativa, devendo para tal organizar novos estatutos, sob pena de dissolução. As associaçôes que agrupassem empresas exercendo a sua actividade apenas no ramo do comércio ou apenas no ramo da indústria, e que não se encontrassem ainda organizadas corporativamente podiam transformar-se em grémios distritais ou concelhios. Já as associaçóes que agrupassem empresas exercendo a sua actividade em vários ramos de comércio ou indústria podiam transformar-se em uniōes de grémios ou podiam pedir a criação de grémios respeitantes a cada um dos ramos, desde que estes não se encontrassem organizados corporativamente, ficando os grémios constituídos ao abrigo deste Decreto-Lei sujeitos ao regime jurídico presente no Decreto-Lei n.o 24715, de 3 de Dezembro de 1934.

As associações que reunissem as condiçôes para a integração na organização corporativa (onde se incluíam a ACIG e a ACB), teriam que elaborar novos Estatutos até 30 de Junho de 1939, submetendo-os à aprovação do Subsecretário de Estado das Corporaçóes e Previdência Social, sob pena de dissolução. É também definido neste decreto que apenas se podiam intitular como grémios, "os organismos constituídos em harmonia com as disposiçóes do Estatuto do Trabalho Nacional e legislação complementar" ${ }^{26}$.

O Decreto-Lei n. ${ }^{\circ} 24715$, de 8 de Dezembro de 1934, ao qual os grémios do comércio de Braga e Guimarães estavam sujeitos, estabelece "o regime jurídico da organização facultativa das actividades comerciais e industriais" ${ }^{27}$.

No distrito de Braga foram criados quatro grémios do comércio, resultados da reconversão de associaçóes comerciais: Guimarães (Abril de 1940); Fafe (Abril de 1940); Braga (Junho de 1940); Barcelos (Agosto de 1940). São ainda criados os Grémios e Esposende (Abril de 1940) e de Vila Nova de Famalicão (Outubro de 1941).

\section{Os Grémios do Comércio dos Concelho de Braga e Guimarães}

A conversão de associação comercial para grémio do comércio implicou mudanças substanciais, visíveis nos novos estatutos dos organismos, em tudo semelhantes. Estes são emblemáticos dos fundamentos formativos do Estado Novo na organização e regulação das actividades económicas. Os objectivos das instituições gremiais consistiam, de acordo com os estatutos, na "disciplina das actividades comerciais que representa,

\footnotetext{
${ }^{26}$ Decreto-Lei 29232, oito de Dezembro de 1938, art. ${ }^{\circ} 11 .^{\circ}$.

${ }^{27}$ Cal. Alexandre Herculano da. Legislação Corporativa. Grémios... p. 9.
} 
repudiando simultaneamente a luta de classes e o predomínio das plutocracias" 28 - em vez do destaque anteriormente atribuído aos interesses do comércio e ao desenvolvimento da região e dos associados (no caso da ACIG, por exemplo). As competências dos grémios estavam subordinadas à organização corporativa, em articulação directa com os órgáos corporativos superiores do Estado e de acordo com o Regimento das Corporaçóes $\left(\operatorname{art.}^{\circ}{ }^{\circ} .^{\circ}\right)$.

As mudanças em termos orgânicos institucionais também são notórias. As antigas Assembleias Gerais, que correspondiam ao poder supremo das associaçóes, lideradas pelos sócios, perdem esse estatuto, constituindo apenas, de acordo com o artigo $5^{\circ}$ dos Estatutos, uma "reunião dos sócios no pleno gozo dos seus direitos" ${ }^{29}$. O número de reunióes diminui significativamente: de duas sessóes anuais, de acordo com os Estatutos de 1925 da ACIG, a periodicidade torna-se bienal. Da mesma forma, as competências e funções dos órgãos directivos registam mudanças relacionadas com a extinção da dinâmica participativa dos sócios nas deliberaçôes dos organismos, que redundam no seu relativo esvaziamento. Em contrapartida, são criados os Conselhos Gerais que absorvem parte das competências das antigas Assembleias Gerais. Por sua vez, as direcçôes são reduzidas a três elementos e começam a desempenhar o papel mais activo na consolidação e liderança dos organismos (art. $\left.{ }^{\circ} 24 .^{\circ}\right)$. A enumeração das competências atribuídas sinaliza a materialização da orgânica corporativa que passa, entre outras atribuições, pela harmonização de contratos colectivos e acordos de trabalho e outros compromissos corporativos; pela organizaçáo dos grupos comerciais de acordo com o universo dos sócios; e pela elaboração anual da lista de sócios.

Mapa I - Área territorial dos concelhos de Braga e Guimarães

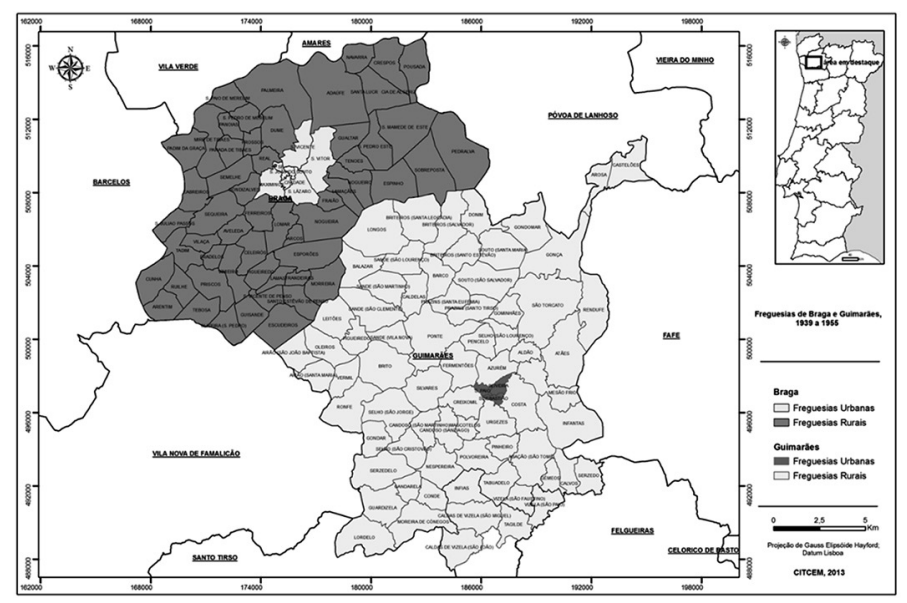

Fonte: Lei n. ${ }^{\circ}$ 63/98, de 1 de Setembro de 1998; Lei n. ${ }^{\circ}$ 62/2003, de 22 de Agosto de 2003.

\footnotetext{
${ }^{28}$ GRÉMIO DO COMÉRCIO DO CONCELHO DE GUIMARĀES (ed.) - Estatutos do Grémio do Comércio do Concelho de Guimarâis. [S.1.: s.n.], 1940. p. 6.

${ }^{29}$ Ibid., p. 11
} 
O concelho de Guimarães correspondia à área administrativa abrangida pelo GCCG, compreendendo um total de 73 freguesias, e uma área aproximada de 256,05 km² (dos quais apenas cerca de $1,43 \mathrm{~km}^{2}$ correspondem a área urbana), existindo três freguesias urbanas e 70 rurais $^{30}$. O recenseamento de 1940 regista 82120 residentes no concelho, 70784 (86\%) em meio rural e 11336 (14\%) em meio urbano. No início da década de 1950 , de acordo com o recenseamento da população, o concelho contava já 97064 residentes, dos quais apenas 11909 (12\%) se encontravam em contexto urbano.

Já o grémio bracarense abrangia, inicialmente, o concelho de $\mathrm{Braga}^{31}$, composto por 61 freguesias - 7 urbanas e 54 rurais - correspondendo a uma área de cerca de 183,4 $\mathrm{km}^{2}\left(171,86 \mathrm{~km}^{2}\right.$ de área rural e 11,64 km² de área urbana). Segundo o recenseamento de 1940 Braga contava 75846 residentes, 29362 (39\%) dos quais em contexto urbano. Já no recenseamento de 1950, existiam no concelho de Braga 84412 residentes, 32153 (38\%) em meio urbano, revelando-se o concelho bracarense com uma maior percentagem de residentes urbanos face a Guimarães na ordem dos $25 \%$.

O GCCG abrangia assim uma área administrativa mais vasta relativamente ao seu homólogo bracarense, no entanto, é no concelho de Braga que se regista uma maior percentagem de urbanização, conforme se pode observar no Mapa I.

\subsection{Os sócios efectivos}

Os sistemas de admissão dos sócios tornaram-se aparentemente mais simples: a ACIG, por exemplo, exigia a boa reputação moral e civil do candidato para a adesão, bem como a maioridade ou equivalente legal; com a conversão em GCCG, o estatuto de sócio efectivo dependia apenas de o candidato ser proprietário de um estabelecimento e estar colectado para efeitos de contribuição industrial.

Os Grémios definiam nos seus Estatutos, duas categorias de sócios: efectivos e auxiliares. O estatuto de sócio efectivo era atribuído, segundo o artigo $9 .^{\circ}$ do Capítulo II dos Estatutos, a "empresas singulares ou colectivas que exerçam o comércio de retalho e não estejam representadas por outro grémio de ramo diferente" 32 , estando obrigadas a cumprir determinadas condiçóes, como a posse de estabelecimento próprio e estar colectado pela contribuição industrial.

Os livros de registos do GCCG apresentam 1329 destes sócios efectivos inscritos entre 1939 e 1955. Já os sócios auxiliares, admitidos pela Direcção e em número praticamente irrisório (50), vão desaparecer a partir de 1946 por imposição superior. O GCCB, por sua vez, regista a entrada de 2813 sócios efectivos em igual período.

Com base nos livros de registos dos organismos e nas fichas individuais dos associados é possível contabilizar o movimento associativo, a nível de entradas, saídas e tempos de permanência.

\footnotetext{
${ }^{30}$ A Lei n. ${ }^{\circ}$ 63/98, de 1 de Setembro de 1998, cria o concelho de Vizela, que absorve cinco freguesias, nomeadamente: São João das Caldas de Vizela, São Miguel das Caldas de Vizela, São Paio de Vizela, Infias e Tagilde que, à época em estudo, se encontram integradas no concelho de Guimarães.

${ }^{31}$ A partir de 1944, passa à designação de pluriconcelhio, abrangendo os concelhos de Amares, Póvoa de Lanhoso, Vieira do Minho, Vila Verde e Terras de Bouro, representando uma área total de 1120,33 km².

${ }^{32}$ GRÉMIO DO COMÉRCIO DO CONCELHO DE GUIMARĀES (ed.) - Estatutos..., p. 8.
} 
Relativamente à entrada de sócios efectivos, os primeiros registos acontecem a 1 de Julho de 1939 (em Guimaráes), apesar de o Grémio ter sido apenas oficialmente criado no ano de 1940 (por alvará de 20 de Abril). Tal deve-se ao facto de as primeiras movimentações no sentido da criação do organismo se realizarem nesse ano através da criação da Comissão Organizadora (que existe entre Julho e Agosto) e da Comissão Directiva, que se manterá em vigor entre Setembro de 1939 e Março de 1942. Em Braga, as primeiras inscriçóes acontecem a 5 de Junho de 1940.

Guimarães alcança o maior número de inscrições em 1940 e 1955; já em Braga, é o ano de 1940 que se destaca, com a inscrição de 940 sócios efectivos, conforme se pode observar no gráfico I.

Gráfico I - entrada/saída de sócios dos GCCG e GCCB, 1939-1955

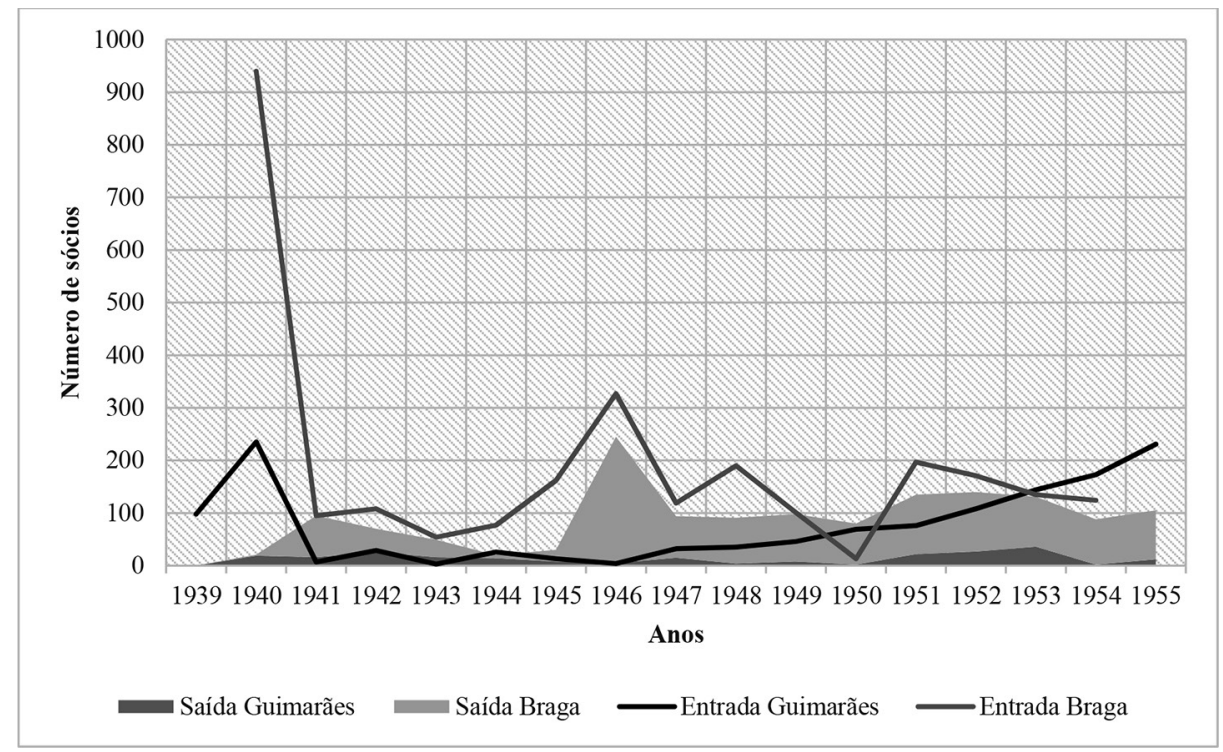

Fonte: livros de registos do GCCG, 1939-1955; fichas individuais dos sócios do GCCB, 1940-1955.

Guimarães apresenta um aumento significativo em 1940, vindo a registar um aumento acentuado e gradual a partir de 1947. Já Braga regista uma evolução inconstante, verificando-se uma tendência de perda a partir de 1951, ainda que, durante a maior parte do período em estudo, apresente valores muito superiores relativamente ao GCCG.

Relativamente à saída de sócios, o GCCG apresenta uma evolução muito regular, registando um aumento entre 1950 e 1953, nunca ultrapassando a marca dos 40 sócios/ano. O GCCB, à semelhança da entrada de sócios, apresenta uma evolução inconstante, atingindo o valor máximo em 1946, quando perde 240 sócios. Depois desse ano, a saída de associados estabiliza, verificando-se um aumento ligeiro entre 1951 e 1952. 
Gráfico II - evolução do saldo de entrada/saída sócios dos GCCG e GCCB, 1939-1955

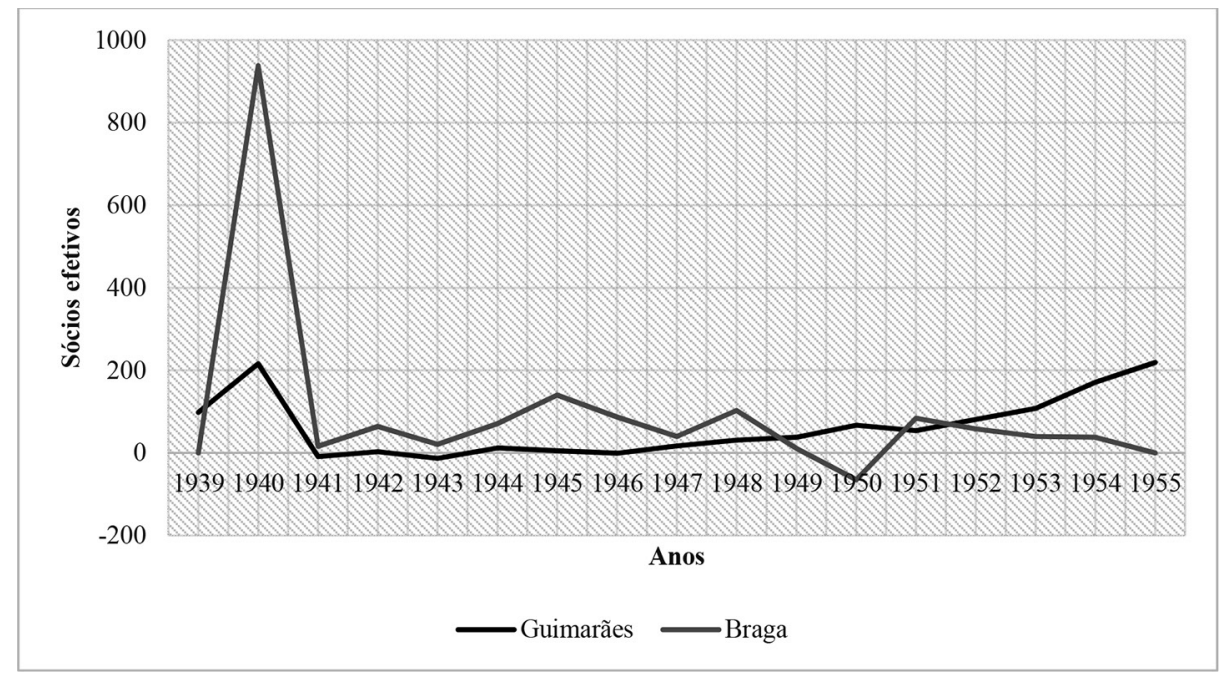

Fonte: livros de registos do GCCG, 1939-1955; fichas individuais dos sócios do GCCB, 1940-1955.

A informação da entrada de novos associados, em conjugação com os dados disponíveis das saídas, permite estabelecer a evolução do movimento dos sócios em ambos os organismos ${ }^{33}$, através da comparação anual das entradas e saídas (gráfico II).

A tendência que se verifica nos dois organismos é algo diferente. Em 1940 regista-se o maior saldo positivo dos dois grémios (216, Guimarães e 938, Braga). A partir daqui a tendência dos dois grémios segue percursos diferentes. Guimarães regista um saldo sempre positivo, experienciando um crescimento gradual. O GCCB, por sua vez, conhece uma evoluçáo inconstante, atingindo mesmo um saldo negativo (-65 sócios) em 1950, recuperando apenas no ano seguinte da tendência de perda.

A conjugação da informação de entrada e saída permite também fazer uma estimativa do tempo que os sócios efectivos permaneceram vinculados aos organismos, ainda que de forma aproximada, já que grande parte da informação relativa à saída dos sócios de Guimarães se encontra incompleta.

Ainda assim, como se pode observar no quadro I, com base nas informaçóes que efectivamente estão disponíveis, é possível concluir que a grande maioria dos sócios efectivos estaria ligada aos Grémios por um período até cinco anos (260, Guimarães; 666, Braga). Muitos associados bracarenses abandonavam ainda no primeiro ano (289); existe ainda um número razoável situado entre os 6 - 10 anos (Guimarães, 100; Braga, 385). Entre 11 e 15 anos, ambos os grémios apresentam percentagens muito semelhantes, sobressaindo o GCCB, com um ponto percentual a mais que o GCCG. Os sócios que permaneceram vinculados aos organismos por mais de 15 anos são

\footnotetext{
${ }^{33}$ Os cálculos apresentados representam uma estimativa, já que a maior parte dos registos não apresentam data de saída.
} 
bastante significativos em Braga, com uma percentagem de 17\%; já Guimarães, conta apenas com 3\% (no entanto, convém destacar, que muitos desses sócios terminam a sua ligação ao GCCG/ACIG já em pleno século XXI).

Quadro I - média de permanência dos sócios efectivos

\begin{tabular}{|l|c|c|}
\hline \multicolumn{1}{|c|}{ Médias de Permanência } & Guimarães & Braga \\
\hline Menos de um ano & $62(5 \%)$ & $289(11 \%)$ \\
\hline $\mathbf{1}$ a $\mathbf{5}$ anos & $260(20 \%)$ & $666(25 \%)$ \\
\hline $\mathbf{6}$ a $\mathbf{1 0}$ anos & $100(7 \%)$ & $385(14 \%)$ \\
\hline $\mathbf{1 1}$ a $\mathbf{1 5}$ anos & $37(3 \%)$ & $120(4 \%)$ \\
\hline Mais de $\mathbf{1 5}$ anos & $39(3 \%)$ & $466(17 \%)$ \\
\hline Sem Informação & $810(62 \%)$ & $792(29 \%)$ \\
\hline
\end{tabular}

Fonte: livros de registos do GCCG, 1939-1955; fichas individuais dos sócios do GCCB, 1940-1955.

Mapa II - distribuição dos associados dos GCCB e GCCG por freguesia, 1940-1955

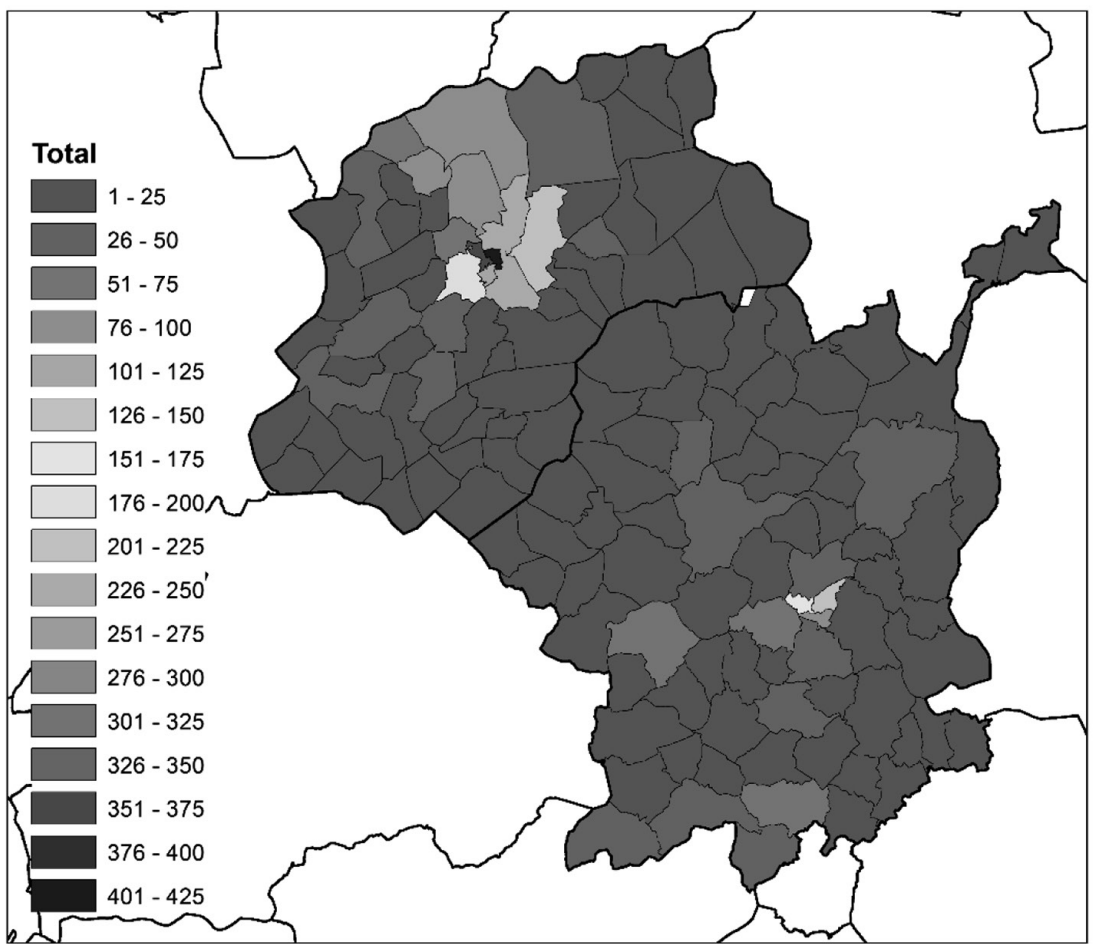

Fonte: livros de registos do GCCG, 1939-1955; fichas individuais dos sócios do GCCB, 1940-1955. 
O Mapa II representa a distribuição do número de associados por freguesia inscritos nos grémios de ambos os concelhos, comparando-os directamente. A análise do mapa permite concluir que a grande maioria das freguesias de ambos os concelhos registam apenas entre um a 25 associados; de igual forma, é possível perceber a existência de algumas freguesias com valores ligeiramente superiores (entre 26 e 75 associados), na periferia da zona urbana e, no caso particular de Guimarães, nas margens do rio Vizela e nas freguesias correspondentes às vilas de Taipas e de Pevidém. Bem visível é o predomínio das freguesias rurais no número de associados, especialmente no concelho bracarense, registando aquelas entre 176 e 425 sócios inscritos no GCCB. Já no concelho de Guimarães, é também nas freguesias urbanas (ainda que apenas em duas das três existentes) que se encontra uma maior densidade de associados, não obstante os valores mais reduzidos, entre 126 e 175 sócios.

\subsection{Os ramos de actividade}

Estes sócios efectivos representavam, em cada um dos Grémios, mais de mil diferentes tipos de actividade/comércio, sendo por isso, os respectivos ramos de comércio exercidos por esses associados agrupados de acordo com o tipo de comércio exercido. Desse agrupamento resultou a criação de 10 grupos de classes, seguindo a classificação das Comissóes de Fixação da Contribuição Industrial e de Reclamaçôes, Grupos B e C, em vigor a partir de 1964, inscritas nos livros de Actas da Direcção do GCCG. Os dez grupos distribuíam-se de acordo com o Quadro II.

Quadro II - distribuição dos sócios efectivos por grupo de comércio/Grémio, 1940-1955

\begin{tabular}{|l|c|c|c|c|}
\hline \multicolumn{1}{|c|}{ Grupos de Comércio } & \multicolumn{2}{c|}{ GC Braga } & \multicolumn{2}{c|}{ GC Guimarães } \\
\hline I - Vestuário e têxteis & 237 & $8,4 \%$ & 109 & $7,9 \%$ \\
\hline II - Géneros alimentícios & 1694 & $60,2 \%$ & 765 & $55,4 \%$ \\
\hline III - Drogaria e ferragens & 297 & $10,6 \%$ & 96 & $7,0 \%$ \\
\hline IV - Agentes/Comissários (a) & 26 & $0,9 \%$ & 64 & $4,6 \%$ \\
\hline V - Electricidade/Electrodomésticos & 23 & $0,8 \%$ & 11 & $0,8 \%$ \\
\hline VI - Móveis & 35 & $1,2 \%$ & 6 & $0,4 \%$ \\
\hline VII - Peles & 5 & $0,2 \%$ & 10 & $0,7 \%$ \\
\hline VIII - Papelaria & 55 & $2,0 \%$ & 19 & $1,4 \%$ \\
\hline IX - Quinquilharia e outros & 55 & $2,0 \%$ & 36 & $2,6 \%$ \\
\hline X - Comércio não especificado (b) & 385 & $13,6 \%$ & 26 & $1,9 \%$ \\
\hline Sem Informação & 1 & $0,0 \%$ & 239 & $17,3 \%$ \\
\hline Total & 2813 & & 1381 & \\
\hline
\end{tabular}

(a) Por agentes/comissários entendem-se aqueles que representam os interesses de outrem.

(b) Neste grupo são colocados todos os negócios que não se enquadram nos restantes grupos.

Fonte: livros de registos do GCCG, 1939-1955; fichas individuais dos sócios do GCCB, 1940-1955. 
Cada um destes grupos englobava uma diversidade de actividades ${ }^{34}$, relacionada com o respectivo sector. Assim, a título de exemplos, o Grupo I - Vestuário, têxteis e calçado, tinha duas vertentes de negócio: o comércio de tecidos e o comércio de vestuário e calçado; já no Grupo II - Géneros Alimentícios, encontramos desde Mercearias, Casas de Pasto até à venda de frutas e legumes; e o Grupo X - Comércio náo especificado, engloba vendedores cujos produtos comercializados nâo eram discriminados, como bicicletas e motocicletas; comércio de jogos (bilhares, alugador de foot-ball de mesa); sector automóvel; música (aluguer de instrumentos musicais); estabelecimento de decoraçóes, oficinas, alugadores de balanças, prédios de revenda; indústria e acessórios; artigos confeccionados e ambulância mista.

Uma ressalva para o grupo Sem Informação, praticamente apenas presente no GCCG, que, como o título indica, é relativo a associados sem dados relativamente ao tipo de actividade/comércio exercido.

Uma breve análise do quadro il revela o domínio do grupo in relativamente a todos os outros, quer no CGGB, quer no GCCG, representando 60\% e 55\%, respectivamente, de todos os associados recenseados. No entanto, a realidade nos concelhos vizinhos difere de forma clara: se no caso bracarense, o grupo II está instalado de forma mais ou menos igualitária entre o meio rural e o meio urbano (com percentagens de $41 \%$ e 59\%, respectivamente), no concelho de Guimarães essa distribuição revela valores bastante distintos, predominando o meio rural com $79 \%$ dos comerciantes da categoria, em relação aos $21 \%$ instalados nas freguesias urbanas do concelho.

Destaque também para as proximidades dos valores de cada grupo no âmbito dos dois organismos, casos dos grupos I e V a IX, com percentagens iguais ou de apenas um ponto percentual de diferença. E se no caso do GCCG a distribuição pelos grupos não apresenta variaçóes de grande ordem (excepção para os grupos II e Sem Informação), no GCCB, além do grupo II, outros dois grupos apresentam percentagens superiores aos 10\%, III - Drogaria e ferragens e X - Comércio não especificado, com 11\% e 14\%, respectivamente.

Os mapas IIIa e IIIb, analisam a implantação de cada um dos grupos de comércio, além do grupo Sem Informaçâo nas freguesias dos dois concelhos, fazendo uma comparação directa dos dados recolhidos em ambos os grémios, sendo possível verificar geograficamente a predominância e a difusão do grupo II, presente, praticamente, na totalidade do território em estudo. Em contraponto, registe-se a pouca difusão do grupo viI, presente em menos de 10 freguesias e com números cuja expressão é residual. Merecem ainda destaque os grupos I e III, difundidos por um número considerável de freguesias de ambos os concelhos, tendo o primeiro particular incidência no concelho vimaranense, de forte tradição industrial têxtil.

\footnotetext{
${ }^{34}$ De ressalvar que em várias ocasiōes as actividades que os sócios do Grémio exercem são bastante variadas, englobando vários dos grupos criados. Nesses casos, o critério de inserção num grupo específico foi a proeminência de um determinado grupo, ou seja, o grupo que estivesse mais representado seria aquele em que a actividade desse sócio seria colocada.
} 
Mapa IIIa - distribuição dos grupos de comércio I, II, V, VI, IX e X por concelho, 1940-1955
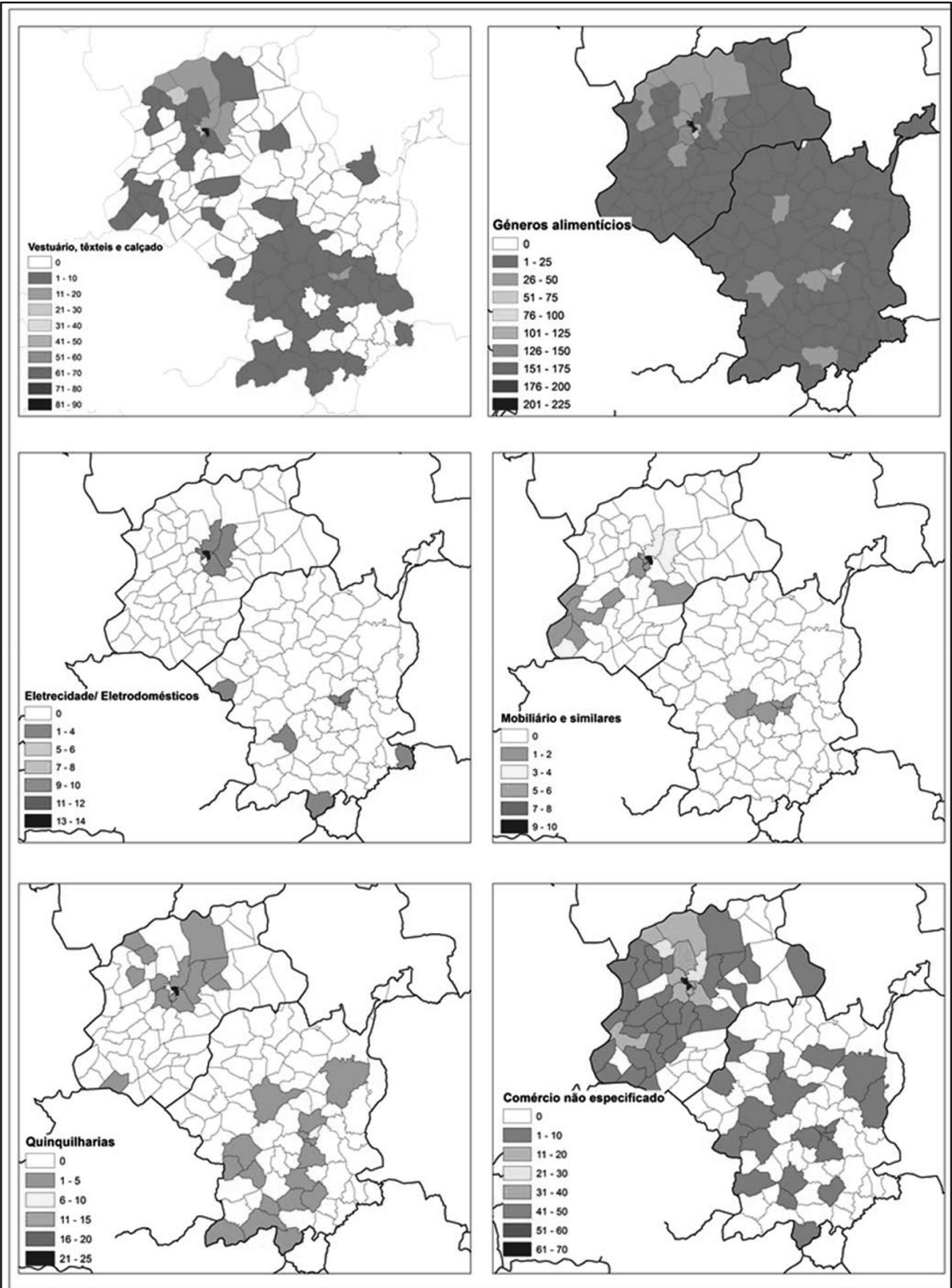

Fonte: livros de registos do GCCG, 1939-1955; fichas individuais dos sócios do GCCB, 1940-1955. 
Mapa IIIb - distribuição dos grupos de comércio III, IV, VII, viII e SI por concelho, 1940-1955

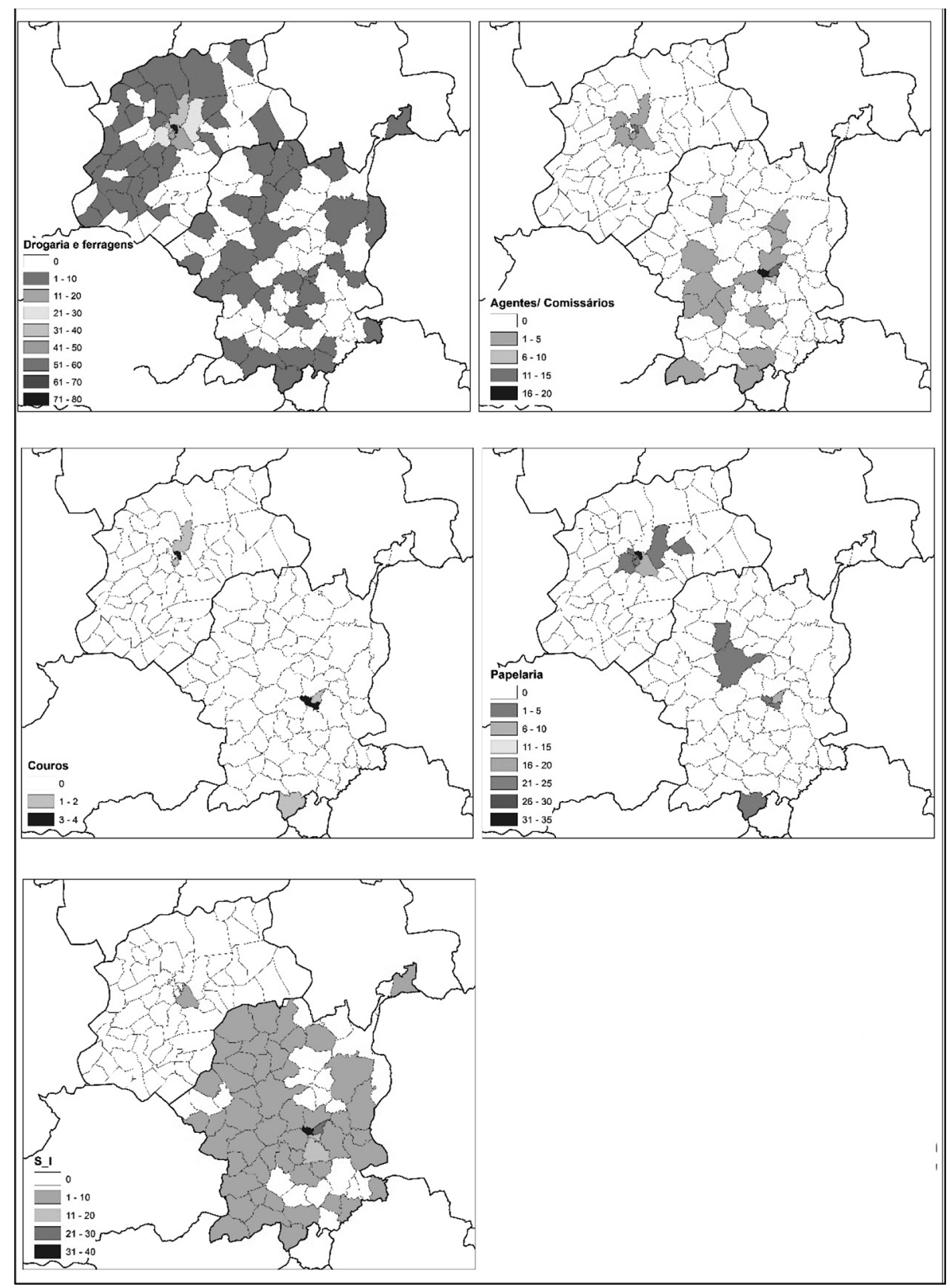

Fonte: livros de registos do GCCG, 1939-1955; fichas individuais dos sócios do GCCB, 1940-1955. 
Todos os comerciantes (sócios ou não) estavam obrigados ao pagamento de quotas mensais para além do pagamento inicial da jóia de inscrição no Grémio (com um valor fixo de $10 \$ 00$ (Capítulo II, artigo $14 .^{\circ}$ ), para efectivos e auxiliares). Já o valor da quota correspondia, para os efectivos, "a 1 por milhar sobre o lucro tributável atribuído para efeito da contribuição industrial paga ao Estado, arredondada em escudos"35, oscilando entre uma quota mínima de $2 \$ 50$ e uma máxima de $30 \$ 00$. A informação relativamente ao pagamento de quotas está apenas disponível no caso do GCCG. Ainda assim, a informação deste grémio pode contribuir para uma melhor compreensão destes organismos a um nível mais vasto.

Os livros de registo da cobrança de quotas do GCCG analisados estendem-se desde 1940 até ao final da década de 1950, exceptuando o ano de 1954 sobre o qual não existem registos. No total existiam 31 escalóes, o mais baixo no valor de $2 \$ 50$, o escalão seguinte era o de $3 \$ 00$, sendo que a partir daqui os escalóes aumentam um escudo cada até se chegar aos $30 \$ 00$.

O cruzamento da informação da cobrança de quotas com a informação dos grupos de comércio permite observar quais os escalóes de quotas que predominavam nos diferentes grupos, bem como os montantes movimentados, conseguindo dessa forma, aferir quais os negócios mais lucrativos à época, uma vez que o escaláo atribuído a cada contribuinte derivava do lucro que este alcançava. Para isso, e para facilitar a leitura da informação, os vários escalóes de quotização foram agrupados em três intervalos: $2 \$ 50-10 \$ 00 ; 11 \$ 00-20 \$ 00$; e 21\$00-30\$00.

Com base no gráfico inI, facilmente se verifica que o primeiro intervalo é o mais representado, na maioria dos grupos, com percentagens em muito superiores aos demais; apenas nos grupos Vestuário e têxteis, Electricidade/Electrodomésticos e Peles não se verifica essa situação. Nos dois primeiros é o terceiro intervalo (21\$00-30\$00) o mais representado (sendo que no grupo $\mathrm{V}$, este intervalo corresponde a 63\%); já no grupo VII, é o segundo intervalo (11\$-20\$) o mais destacado. Este segundo intervalo surge ainda com uma presença relativamente sólida em quase todos os grupos, excepção para os grupos Géneros alimentícios, Móveis e Comércio não especificado. Já o terceiro intervalo não está presente nos grupos VI, IX e X, com uma representação residual nos grupos II e viII.

35 GCCG. Estatutos, p. 11. 
Gráfico III - representatividade dos escalôes de quotização nos grupos de comércio do GCCG, 1940-1959

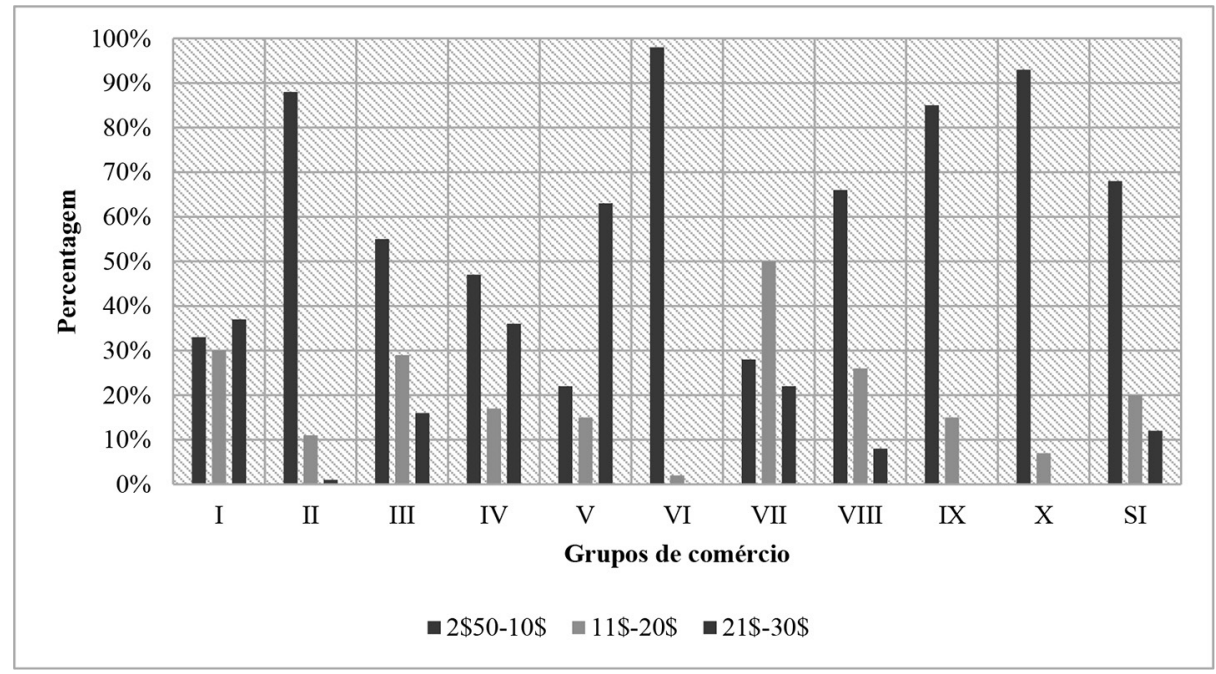

Fonte: livros de registos do GCCG, 1939-1955; fichas individuais dos sócios do GCCB, 1940-1955.

Assim, pode concluir-se que os grupos mais lucrativos eram os relacionados com os têxteis e a electricidade; por sua vez, o grupo menos lucrativo seria o dos Móveis, com o primeiro intervalo a representar $98 \%$, seguido do Comércio náo especificado, com 93\%. O sector alimentar, apesar de ser de todos aquele com mais contribuintes, era também dos menos lucrativos, com o primeiro intervalo a representar $88 \%$ dos seus contribuintes.

\section{Conclusão}

A instituição dos grémios do comércio veio trazer alteraçóes de fundo ao panorama associativo patronal português, sobretudo no caso das associaçôes comerciais e industriais, como era o caso da ACIG. O foco das preocupações destas instituições deixa de estar, pelo menos estatutariamente, voltado para a defesa do comércio [e da indústria] e dos seus associados, ficando subjugadas à orientação política imposta pelo Estado Novo, integrando a organização corporativa enquanto elementos primários, sob orientação directa do delegado distrital do INTP.

As realidades associativas de ambos os organismos (analisando apenas a situação nos concelhos sede) revelam situaçóes distintas, desde logo pelo número de associados registados em ambos os organismos no período em estudo: o GCCB regista mais $34 \%$ do que o seu homólogo vimaranense, ainda que o concelho de Guimarães fosse descrito em 1940 pelo Delegado do INTP em Braga, Henrique Cabral Noronha e 
Menezes, como "o principal centro de vida corporativa e de trabalho deste Distrito" 36 e o GCCG fosse, naquele ano, o grémio do comércio do distrito com o maior número de associados e aquele com os maiores valores de receita e despesa (sendo ultrapassado nos anos seguintes pelo GCCB). O movimento associativo dos dois organismos conheceu tendências e momentos distintos, registando-se, simultaneamente, tendências de crescimento e de perda de sócios, em especial na década de 1950.

Relativamente às dinâmicas comerciais, aí o panorama já se apresenta de outra forma, sendo evidentes as semelhanças entre os dois organismos, com os 10 grupos do comércio a apresentarem valores muito semelhantes no nível de sócios registados e na sua distribuição a nível urbano/rural.

Os grémios do comércio de Braga e Guimarães surgiram no advento do lançamento da organização corporativa patronal - ainda que com passados e trajectórias distintas - e ainda que assumindo diferentes características, sobretudo pela tipologia de que é revestido o GCCB (dotado de carácter pluriconcelhio), as semelhanças entre os dois organismos, por força de imposição superior, serão maiores que as diferenças ditadas pelos diferentes contextos administrativas e espaciais.

Ainda assim, para uma melhor compreensão do funcionamento destes organismos, seria importante conhecer um pouco mais da sua realidade, decorrendo sobre a sua própria actividade e a sua intervenção na vida concelhia (através da análise das actas e da imprensa local, por exemplo), e dos corpos gerentes que os compunham, tendo em conta não só a sua presença no plano político, civil e social das respectivas localidades, mas também tendo em conta a sua actividade comercial, na sua dimensão e valor económico ${ }^{37}$.

Importaria ainda uma análise mais abrangente, em especial com organismos congéneres de outras regiôes do País (como as Beiras ou o Alentejo), onde a realidade da organização corporativa comercial patronal adoptou formas distintas, sobretudo pela área administrativa atribuída aqueles grémios, mas também aos grémios de Coimbra, Porto e Lisboa, de carácter distinto dos restantes grémios comerciais facultativos do país (grémios de comércio retalhista diferenciado).

\section{Bibliografia}

AMARAL, Diogo Freitas do - "Corporativismo, Fascismos e Constituição". In Corporativismo, Fascismos, Estado Novo. Coimbra: Almedina, 2012. p. 81-98.

BASTOS, Carlos - Livro de Ouro do Comércio e Indústria de Portugal. Porto: Edição de autor, 1957.

CACHADA, Armindo - "Associação Comercial e Industrial de Guimarães, Subsídios para a sua história”. Boletim Informativo Ediçâa Especial, 125 anos. (1990).

\footnotetext{
${ }^{36}$ Arquivo da unidade local da Autoridade para as Condiçôes do Trabalho de Braga [ACT Braga], Relatório 1940, fl. 4.

${ }^{37}$ Cfr. TORRES, Jorge Mano - Os comerciantes e o Grémio do Comércio de Guimarães : dinâmicas associativas, corporativas e comerciais (1939-1969). Braga: Instituto de Ciências Sociais, Universidade do Minho, 2013.
} 
CARDOSO, José Luís - "Corporativismo, Instituições Políticas e Desempenho Económico". In Corporativismo, Fascismos, Estado Novo. Coimbra: Almedina, 2012.

FERREIRA, Nuno Estêvão - "O corporativismo e as instituições do salazarismo: a Câmara Corporativa (1935-1945)". In O Corporativismo em Português. Lisboa: Imprensa da Ciências Sociais, 2008.

FREIRE, Dulce; ESTÊVÃO FERREIRA, Nuno; RODRIGUES, Dulce - Corporativismo e Estado Novo. Contributo para um roteiro de arquivos das instituiçóes corporativas (1933-1974). Lisboa: ICS Working Papers, 2014.

GAGLIARDI, Alessio - Il corporativismo fascista. Bari: Gius, Laterza \& Fligi, 2010.

GARRIDO, Álvaro - "Contexto, fundamentos e lógicas de construçâo da economia nacional corporativa”. In Corporativismo, Fascismos, Estado Novo. Coimbra: Almedina, 2012. p. 143-164.

GARRIDO, Álvaro - "Estado corporativo, economia institucionalizada". In Estado, Regimes e Revoluçôes: Estudos em homenagem a Manuel de Lucena. Lisboa: Imprensa das Ciências Sociais, 2012.

GRÉMIO DO COMÉRCIO DO CONCELHO DE GUIMARÃES (ed.) - Estatutos do Grémio do Comércio do Concelho de Guimaräis. [S.1.: s.n.], 1940.

LUCENA, Manuel de - A evolução do sistema corporativo português. Lisboa: Perspectivas \& Realidades, 1976.

OLIVEIRA, Eduardo Pires de - História da Associação Comercial de Braga. Braga: Associação Comercial de Braga, 2000.

RODRIGUES, Cristina - Portugal e a Organização Internacional do Trabalho (1933-1974). Porto: Afrontamento, 2013.

ROSAS, Fernando - "Portugal e o Estado Novo". In Nova História de Portugal. Lisboa: Presença, 1987.

ROSAS, Fernando - Salazar e o poder: a arte de saber durar. 1. ${ }^{\text {a }}$ ed. Lisboa: Tinta-da-China, 2012.

ROSAS, Fernando; GARRIDO, Álvaro - Corporativismo, Fascismos, Estado Novo. Coimbra: Almedina, 2012.

SANTOS, Paula Borges - "O modelo político do Estado autoritário Português: A ideia corporativa na constitucionalização do regime (1931-1933)”. Espacio Tiempo y Forma. Serie V, Historia Contemporánea. Vol. 0, n. ${ }^{\circ} 27$ (2015) p. 59-84.

TORRES, Jorge Mano - Os comerciantes e o Grémio do Comércio de Guimarães: dinâmicas associativas, corporativas e comerciais (1939-1969). Braga: Instituto de Ciências Sociais, Universidade do Minho, 2013. 